\title{
Research on Problems of Course Construction in Applied College and Its Countermeasures
}

\author{
Lihua Huang \\ Fuzhou University of International Studies and Trade \\ Fuzhou, Fujian, China
}

\begin{abstract}
At present, the society has increasingly high requirements for talent training. New requirements are put forward for course construction to better build applied college. This paper mainly analyzes problems of applied college in course construction including lack of competent teachers, weak practical teaching, separation of development technology of teaching resources and course construction and unsound compilation level of teaching materials. It also proposes the countermeasures like strengthen the construction of teaching body, expand and optimize course experiment platform, pay attention to compilation of teaching materials and establish reasonable assessment mechanism, in order to promote the course construction in applied universities.
\end{abstract}

Keywords-applied college; course construction; countermeasure

\section{INTRODUCTION}

The course construction of applied college is one of the ways to check teaching quality as well as one of the crucial contents to deepen teaching reform in professional construction. Universities carry out course construction successively to improve teaching quality and better meet the construction of applied college. The course construction needs to use modern information technology to present the course contents and share it on the network for free [1], embodying the sharing and epochal character of teaching resources and vitalizing the course construction, in order to promote the smooth implementation of course construction in applied college.

\section{CURRENT Situation OF COURSE CONSTRUCTION IN APPLIED COLLEGES}

The primary task of applied college is to train applied talents. [2] The talent training and course construction in applied colleges differs from that of academic colleges and vocational college. It emphasizes the application of basic knowledge and professional skills in professional practice. At present, many applied colleges still excessively pursue the integrated and systematic theoretical knowledge and neglect the training of practical ability, students' ability in solving problems and innovation ability, failing to use theoretical knowledge to guide the practice. Therefore, it requires applied colleges to update teaching idea and objectives in teaching reform, adjust syllabus and teaching contents, innovate in teaching methods, strengthen practical teaching and avoid the homogenization with other colleges.

\section{PROBLEMS IN COURSE CONSTRUCTION OF APPLIED COLLEGES}

\section{A. Lack of Competent Teachers in Course Construction}

Applied colleges have a short history after construction or transformation. Therefore, it is short of competent teachers. The knowledge reserve of teachers comes from the understanding of theory. They lack experience of practice in enterprises. So they are not double-professionally-titled teachers. At present, most teachers still follow the traditional teaching methods to solve the problem of lacking theoretical and practical experience. So they fail to meet the requirements of applied colleges for students' abilities in analyzing, dealing with and solving problems. At present, the course construction in applied colleges requires teachers with high quality, active thinking and strong sense of responsibility. More important, course teachers should have rich teaching experience and theoretical and practical knowledge and be familiar with the latest trend of academic development at home and abroad. In reality, the construction of teaching body in many colleges fails to meet the requirements. They carry out course construction narrowly because of the insufficient competent teachers. Teachers in applied colleges are too young and prentice.

\section{B. Weak Practical Teaching in Course Construction}

Courses include the theoretical and the practical. The course construction should train students' ability in dealing with practical problems and challenges and proposing innovative methods in solving problems. Courses have high requirements for practice. Because of insufficient school funding, some colleges fail to invest enough funds, leading to inadequate software and hardware facilities in course teaching. They are forced to reduce the class hour of practical course and increase the class hour of theoretical course, which is difficult to meet the requirements of applied colleges for combination of theory and practice and adverse to training students' operational and innovation ability.

Fund project: school level key construction course project: Human resource management (J2016013). 


\section{Separation of Development Technology of Teaching Resources and Contents of Course Construction}

Undoubtedly, high quality teaching resources are important to course construction and the teaching of students. Courses include theoretical courses (not include practice), theoretical courses (include practice) and practical courses. The course construction can carry out from syllabus, teaching, teaching courseware, problem sets, case library and references. Some applied colleges pay inadequate attention to course construction and the development of teaching resources, so they fail to meet the requirements of course construction. Furthermore, problems exist in information technology and teaching knowledge technology in course construction. At present, few talents can meet the two requirements. Talents familiar with technology lack basis of teaching knowledge and teachers familiar with teaching knowledge fail to grasp information technology. Therefore, the course websites are not sound and the contents are single. The development of teaching resources separates from course construction, influencing teaching effects.

\section{Imperfect Compilation of Teaching Materials in Course Construction}

In course construction of applied colleges, the teaching materials should be authoritative and follow the trend of the times. The update of knowledge on teaching materials for applied colleges should keep pace with the times. Backward opinions, ideas and theoretical research in it should be updated. $\mathrm{T}$ present, applied colleges continuously reform teaching contents and course system and update teaching materials. However, they neglect the construction of experimental or practical teaching materials. Some still use outdated teaching materials that fail to meet the requirements of course construction.

\section{Measures to Solve Problems In CoUrSe CONSTRUCTION OF APPLIED COLLEGES}

\section{A. Strengthen the Construction of Teaching Body}

The quality and proportion of teaching body is important for applied colleges in teaching activities and scientific research, guiding students to learn theoretical knowledge and training their practical ability. The quality of teachers directly influences the effect of course construction. Therefore, it is necessary to strengthen the construction of teaching body and improve teaching methods and quality of talent training in applied colleges. Firstly, applied colleges should pay attention to and train double-professionally-titled teachers suitable for course development and improve their application level and ability. "Introduce" enterprise personnel with rich experience and good expression ability to teach practical contents in class. Secondly, "send" course teachers to enterprises to train. Thirdly, train double-professionally-titled teachers. Teachers in school attach importance to theoretical knowledge and experienced enterprise personnel explain practical knowledge and guide students in practice. Therefore, full-time teachers on campus and part-time teachers outside school can form a sound teaching body of course construction.

\section{B. Innovate the Methods of Practical Teaching}

In course construction, applied colleges should build comprehensive laboratory on campus and off-campus laboratory with enterprises to support practical teaching and expand practice base to help students better understand and learn occupational knowledge and skills. Students can operate with local enterprises and experience the management knowledge learned in school through on-site visiting and practice. Besides, schools can extend the practical teaching link and make proper talent training scheme and guide students $\mathrm{n}$ social investigation and practice. In order to broad students' horizon and improve their innovation and management skills, schools can encourage teachers and students to practice in enterprises and invite some management personnel with theoretical knowledge and practical ability in enterprises to give lectures to improve the practical teaching. It will improve students' ability in adapting to the society, better serving the society and cooperation.

\section{Expand and Optimize Course Experiment Platform}

The experiment link in teaching can guarantee the course teaching complies with talent training objectives of applied colleges and train students' manipulative, practical and innovation ability. Therefore, it needs to expand and optimize the experiment platform of course construction in innovation of experiment pattern and reform of experiment effect. The improvement of students' practical ability relies on the experiment platforms in and outside the school. The integration of theory and practice can arouse students' enthusiasm and interest of learning [3]. In course construction, applied colleges can build comprehensive laboratory on campus and off-campus comprehensive laboratory together with enterprises and invite experienced experts to guide. In addition, applied colleges can increase the teaching input of course construction, build laboratory and simulation room, such as ERP simulation laboratory or 3D interactive laboratory. University-enterprise cooperation is also effective.

\section{Pay Attention to Compilation of Teaching Material}

Some teaching materials often separate from the reality and fail to keep pace with the times. The existing excellent teaching materials can be used as teaching reference books. Applied colleges can integrate the contents of professional qualification examination in course construction and make the teaching contents more practical. Moreover, course teachers can compile applied teaching materials combining cases and situational teaching with professional teachers in other colleges. Applied colleges can organize experienced people and those with practical ability to compile supporting teaching materials and practice library conforming to social practice and students' ability.

\section{E. Establish Reasonable Evaluation System}

The teaching assessment of applied colleges can base on evaluation system which can test the learning effect of students and teaching quality and effects of teachers and help schools to find out defects in teaching and improve. Reasonable and diversified evaluation system can be established by industry association, enterprise, applied colleges and employers, in 
order to train students' ability in analyzing, solving problems and innovation ability as well as practical ability. The followup survey of graduates is helpful. Applied colleges can optimize evaluation systems of course construction and experimental link. These measures can arouse students' initiative in course construction, train their interests and make them correctly understand the weak links and correct timely, so that they can better and faster improve adaptive capacity in working.

\section{CONCLUSION}

Universities pay more and more attention to the transformation to applied college through necessary course construction. But diversified problems may appear in this process. Therefore, it is of vital importance to take essential measures to promote course reform.

\section{REFERENCES}

[1] Sheng Zhengfa. Analysis of National Excellent Course Construction in Implementation of Quality Engineering [J], Higher Education Development and Evaluation, 2009(3): 100-105

[2] Zhu Kai. Thinking on Development from Traditional Undergraduate College to Applied One [J], Shandong Youth Monthly, 2015(1):21-22

[3] Yang Zhenguo. Application of Practical Teaching Method in College Course [J], Career Horizon, 2014(12): 53-55.. 